\title{
Sitting forward bending position versus standing position for studying the back shape in scoliotic children Tomasz Kotwicki*1, Joanna Chowańska ${ }^{1}$, Edyta Kinel ${ }^{2}$, Małgorzata Lorkowska ${ }^{1}$, Wanda Stryła ${ }^{2}$ and Andrzej Szulc ${ }^{1}$
}

\author{
Address: ${ }^{1}$ Department of Pediatric Orthopedics and Traumatology, University of Medical Sciences of Poznan; ul. 28 Czerwca 1956 roku nr 135; \\ 61-545 Poznan, Poland and 2Department of Rehabilitation, University of Medical Sciences of Poznan; ul. 28 Czerwca 1956 roku nr 135; $61-545$ \\ Poznan, Poland \\ Email: Tomasz Kotwicki* - kotwicki@amp.edu.pl \\ * Corresponding author
}

\author{
from 4th International Conference on Conservative Management of Spinal Deformities \\ Boston, MA, USA. 13-16 May 2007 \\ Published: 12 October 2007 \\ Scoliosis 2007, 2(Suppl I):S34 doi:I0.I I86/I748-7|6I-2-SI-S34
}

This abstract is available from: http://www.scoliosisjournal.com/content/2/SI/S34

(c) 2007 Kotwicki et al; licensee BioMed Central Ltd.

\section{Objective}

Potential benefits of sitting position for scoliosis exam include stable posture and level pelvis. The hypothesis was that surface topography as well as scoliometer evaluation can be performed in sitting forward bending position and that the parameters describing deformity in the frontal and axial plane can be provided.

\section{Study design}

Cross sectional study of 113 girls with idiopathic scoliosis, aged $14.0 \pm 2.1$ years (range 10 to 18 ), mean height 160.0 $\pm 9.4 \mathrm{~cm}$ (range 121 to 184 ), mean weight $48.6 \pm 9.2 \mathrm{~kg}$ (range 22 to 75 ) who underwent raster stereography exam of the back in standing position and in sitting forward bending position. The Cobb angle of the main curve was $41.2 \pm 16.7$ degrees (range 10 to 95 ), Risser sign value from 0 to 5 , median $=2$.

\section{Methods}

Spine length (C7-S1), Hump Sum and posterior trunk symmetry index (POTSI) were measured [1]. Bunnell scoliometer [2] was used to measure angle of trunk rotation (ATR) in standing position at three levels of the spine and the Sum of Rotation was compared with the Hump Sum. Additionally 49 girls, having scoliosis of 10 to 70 degrees of Cobb angle, were examined for ATR both in standing forward bending (Adams' test) and in sitting forward bending position.

\section{Results}

Spine length was $41.5 \pm 3.5 \mathrm{~cm}(29.8-49.9 \mathrm{~cm})$ in standing and $46.5 \pm 3.5 \mathrm{~cm}(35.0-53.4 \mathrm{~cm})$ in sitting forward bending position (mean difference $5.0 \pm 2.7 \mathrm{~cm}, \mathrm{p}<0.05$, Mann Whitney U test) proving that flexion of the trunk was achieved. The Hump Sum value was $21.3 \pm 7.7$ degrees in sitting and $19.0 \pm 6.6$ degrees in standing position ( $\mathrm{p}<0.01)$. The correlation coefficient for Hump Sum vs Sum of Rotation was 0.71 for the sitting and 0.49 for the standing position $(\mathrm{p}<0.05)$. POTSI was $23.3 \pm 13.8$ in sitting and $28.9 \pm 17.5$ in standing position $(\mathrm{p}<0.001)$. The ATR was not distinct between standing and sitting forward bending position ( $\mathrm{p}>0.05)$.

\section{Conclusion}

Back asymmetries in children can be measured successfully in sitting forward bending position. This position provides a more stable posture and eliminates the impact of lower limb discrepancy, and therefore may be considered a recommended position for scoliosis exam using scoliometer or surface topography.

\section{References}

I. Asher M, Lai S, Burton D, Manna B: Maintenance of trunk deformity correction following posterior instrumentation 
and arthrodesis for idiopathic scoliosis. Spine 2004, 29: $1782-1788$.

2. Bunnell WP: An objective criterion for scoliosis screening. J Bone Joint Surg 1984, 66A: | 38I-1387.

Publish with Bio Med Central and every scientist can read your work free of charge

"BioMed Central will be the most significant development for disseminating the results of biomedical research in our lifetime. " Sir Paul Nurse, Cancer Research UK

Your research papers will be:

- available free of charge to the entire biomedical community

- peer reviewed and published immediately upon acceptance

- cited in PubMed and archived on PubMed Central

- yours - you keep the copyright

Submit your manuscript here:

http://www.biomedcentral.com/info/publishing_adv.asp 